2013-08-01

\title{
The MinK Framework: Towards Measuring Individual Knowledge
}

Mohamed Ragab

Technological University Dublin, mohamed.af.ragab@gmail.com

Amr Arisha

Technological University Dublin, amr.arisha@tudublin.ie

Follow this and additional works at: https://arrow.tudublin.ie/buschgraart

Part of the Business Administration, Management, and Operations Commons

\section{Recommended Citation}

Ragab, M. \& Arisha, A. (2013), The Mink Framework: Towards Measuring Individual Knowledge, Journal of Knowledge Management Research \& Practice, Vol. 11, no. 3. doi: 10.1057/kmrp.2013.40.

This Article is brought to you for free and open access by the Graduate Business School at ARROW@TU Dublin. It has been accepted for inclusion in Articles by an authorized administrator of ARROW@TU Dublin. For more information, please contact arrow.admin@tudublin.ie, aisling.coyne@tudublin.ie,gerard.connolly@tudublin.ie. Funder: College of Business - DIT 


\section{The MinK framework: towards measuring individual knowledge}

\author{
Mohamed A.F. Ragab ${ }^{1}$ and \\ Amr Arisha ${ }^{1}$ \\ ${ }^{1} 35$ Group, College of Business, Dublin Institute of \\ Technology, Ireland
}

Correspondence: Mohamed A.F. Ragab, College of Business, Dublin Institute of Technology, Aungier Street, Dublin 2, Ireland. E-mail: mohamed.ragab@mydit.ie

\begin{abstract}
Knowledge is the currency of the current economy and a vital resource for sustaining organisational performance in today's knowledge-based intensively competitive business environment. To avoid the detrimental consequences of knowledge loss, managers are urged to identify where knowledge stocks exist and how knowledge flows within their organisations by identifying knowledge holders among their employees. Although some studies have attempted to use different methods to measure knowledge at the organisational level, very few have addressed the individual knowledge holder. Moving from a critical literature review of the existing knowledge measurement approaches, this paper proposes a novel framework that enables organisations to measure individual knowledge in the business context using a set of metrics, which are subsequently validated via a series of in-depth interviews with senior managers. A summary of the managers' views on individual knowledge measurement is presented, and reflections on the industry application of the proposed framework and recommendations for its improvement are also discussed.

Knowledge Management Research \& Practice advance online publication, 19 August 2013, doi:10.1057/kmrp.2013.40; corrected online 26 August 2013
\end{abstract}

Keywords: knowledge stocks and flows; measurement; performance management; knowledge management tools

\section{Introduction}

Knowledge is recognised as a foundation of sustainable quality and competitive advantage in the current era, when business is both complex and dynamic (Pacharapha \& Ractham, 2012). The ability of organisations to create value is no longer solely dependent on their financial and physical capital, but rather on their capacity to acquire, create and utilise knowledge (Carmeli \& Tishler, 2004). Given that knowledge is the main value driver in today's businesses, the focus on the management of knowledge as a strategic resource has given rise to the Knowledge Management (KM) field, which has grown exponentially over the last decade (Serenko et al, 2010). However, reflecting the truth of the saying 'if you can't measure it, you can't manage it', the measurement of an organisation's knowledge resources has emerged as a key area of interest for both researchers and practitioners in the KM domain (Skyrme, 2003).

Despite being one of the most challenging activities in KM (Chen et al, 2009), the measurement of knowledge is needed to achieve two organisational objectives: internal monitoring and external presentation. From an internal perspective, managers may not know the full extent of the knowledge that exists within their own organisations, as the CEO of Hewlett-Packard once famously said: 'If only HP knew what HP knows, we would be three times as profitable' (Davenport \& Prusak, 2000). In such cases, knowledge measurement is essential to reveal 'hidden' knowledge assets, leading 
to more effective KM (Edvinsson \& Malone, 1997). Knowledge measurement can also be crucial to the implementation of $\mathrm{KM}$ initiatives, as it allows the effects of $\mathrm{KM}$ on organisational knowledge to be evaluated, thus justifying the often substantial costs of $\mathrm{KM}$ implementation (Liebowitz \& Suen, 2000; Khalifa et al, 2008). From an external viewpoint, the mounting gap between companies' book and market values has led to the widespread view that a company's 'true' value must include the value of all its intangible assets (Boda \& Szlavik, 2007). From this perspective, a company's value is seen as the aggregation of its financial capital and its intellectual capital (Galbraith, 1969), which refers to its 'packaged useful knowledge' (Stewart, 1998). In the traditional conceptualisation where organisational knowledge is envisaged as a series of 'stocks and flows', Intellectual Capital (IC) can be seen as referring to the stock of knowledge an organisation holds at a certain time, while KM is concerned with the 'flows', that is, with acquisition and sharing of such knowledge (Bontis et al, 1999; Al-Laham et al, 2011).

The need to measure knowledge - so as both to enhance its management and to enable the 'true' valuation of companies - has led researchers to propose a number of knowledge measurement frameworks. However, the majority of their models have attempted to measure knowledge at a company level, while very few efforts have been directed towards measuring the knowledge held by individual employees, although they are the major source of any organisation's knowledge (Kannan \& Aulbur, 2004). In their classic work two decades ago, Nonaka \& Takeuchi (1995) stated, 'Knowledge is created only by individuals. An organisation cannot create knowledge on its own', 'Organisational knowledge creation should be understood as a process that organisationally amplifies the knowledge created by individuals'. Fahey \& Prusak (1998) agreed, pointing out that 'there is no knowledge without someone knowing it', and they list seeing knowledge in isolation from 'the knowers who own it' among their list of 'Gravest KM Mistakes'. Since knowledge identification is a core KM activity (Heisig, 2009), the success of an organisation's KM efforts will largely depend on its ability to identify the individual creators and carriers of knowledge before seeking to implement other KM activities such as knowledge sharing and utilisation. Identifying knowledge holders will also contribute to reducing knowledge loss, as it would allow managers to take measures to ensure that those who hold vital knowledge remain within the organisation by offering them appropriate compensation, longer contracts and loyalty programmes. But despite its cardinal importance, the measurement of individual knowledge remains a comparatively unexplored subdomain of knowledge measurement and KM.

This study attempts to address this lack by proposing a new framework, referred to as MinK, an acronym for Measuring Individual Knowledge. The objective of the MinK framework is to provide managers with a comprehensive tool to allow them to assess individual knowledge, despite the complexities surrounding the process. As part of the process of achieving this objective, a succinct critical review of the different existing methods used to measure knowledge in the KM literature is provided below, along with a discussion of the main frameworks used by each method. The development of MinK is then described and the model's structure is presented. A pilot study aimed at its preliminary validation is then introduced, followed by the study's findings and some recommendations for future research.

\section{Literature review}

Initially, the authors aimed to review the KM literature on individual knowledge measurement. However, given the dearth of research addressing knowledge measurement on the individual level, the literature review had to be extended to encompass organisational models to enable the authors to identify the different approaches researchers have applied to measure knowledge (Skyrme, 2005). The KM literature on organisational knowledge measurement offers an array of measurement models among which three main groups can be identified: (1) Financial Methods, (2) IC Components Methods, and (3) Performance Methods.

\section{Financial methods}

In the first approach, data from a company's financial results and records is used to compute IC in financial terms. Table 1 lists the most widely cited models and their respective knowledge valuation methodologies.

\section{IC components methods}

The second approach divides IC into different components, each of which is then measured individually (Luthy, 1998). Most such methods tend to apply at least the first two of the following four steps:

Classification: An organisation's IC is broken down into its components, usually Human Capital (HC) - the combined knowledge of its employees - and Structural Capital (SC), which refers to '[knowledge] left when employees have gone home', including that held within the company's supportive infrastructure, business processes, IT systems and customer relations (Bose, 2004). SC may be further sub-divided into Organisational Capital and Customer Capital (Edvinsson, 1997).

Metric Development: Metrics are selected to measure each IC component.

Aggregation: IC measures are aggregated into one numerical figure using such methods as averages, weighted averages, etc., to produce a single number value that reflects the company's IC.

Financial Valuation: The financial value of a company's IC may be computed and presented in monetary terms, or a correlation may be established between the figure that represents the IC value and some financial indicator. Table 2 summarises the IC Components frameworks most widely cited in the KM literature. 
Table 1 Financial knowledge measurement methods

\begin{tabular}{ll}
\hline Model & Methodology \\
\hline $\begin{array}{l}\text { Tobin's Q } \\
\text { (Tobin, 1969) }\end{array}$ & $\begin{array}{c}\text { Measures knowledge as the ratio between a company's market value and its book value. A Q higher than } 1 \text { is an } \\
\text { indicator of the ability to create value by utilising knowledge }\end{array}$ \\
$\begin{array}{c}\text { Economic Value Added (EVA) } \\
\text { Applying } 164 \text { adjustments to traditional balance sheets to account for intangibles after which EVA is calculated } \\
\text { (Stewart, 1994) }\end{array}$ & $\begin{array}{l}\text { by deducting the cost of capital from operating profit (Weaver, 2001) } \\
\text { Human Resource Accounting }\end{array}$ \\
$\begin{array}{l}\text { Uses three types of models: } \\
\text { (HRA) }\end{array}$ & $\begin{array}{l}\text { Cost models - Value human capital comprising knowledge as the cost of acquiring human assets } \\
\text { (Hermanson, 1964) }\end{array}$ \\
$\begin{array}{l}\text { - Income models - Use the present value of the revenues an employee is expected to generate while working } \\
\text { for a company as a measure of his/her knowledge (Flamholtz et al, 1993) }\end{array}$ \\
$\begin{array}{l}\text { Coefficient (VAIC) } \\
\text { (Pulic, 2000) }\end{array}$
\end{tabular}

\section{Performance methods}

While a number of researchers have designed models to measure knowledge, others have adopted the view that its fluid and complex nature means knowledge cannot be measured, but that only the effects or outcomes of its use are measureable (Liebowitz \& Wright, 1999). Hence, research in this third knowledge measurement approach directs its efforts towards measuring the impact of applying knowledge with the aim of establishing links between KM and improved organisational performance, even though the literature acknowledges such links may remain nebulous (Petra \& Annelies, 2012). The method normally applied involves comparing an organisation's performance before a KM process is inaugurated and after it has been implemented, to identify its performance effects. Such studies adopt various methodologies to evaluate organisational performance, mostly either quantitative or qualitative (Huang et al, 2007). Quantitative performance measurement methods generally use financial indicators, such as profitability or return on investment, or non-financial indicators, such as cycle time or number of complaints. Qualitative methods rely on surveys, questionnaires or interviews to gain feedback on the performance effects of KM. Finally, some KM researchers assess performance by using The Balanced Scorecard, one of the most popular and comprehensive performance measurement tools, which comprises quantitative, qualitative, financial, and nonfinancial measures (Kaplan \& Norton, 1996).

In summary, a review of the literature reveals three main perspectives to knowledge measurement on the organisational level. The financial perspective provides a concise unbiased overview of a company's IC and may be beneficial in investment decisions and benchmarking, but does not elucidate where KM problems exist, nor suggest what actions should be taken to improve knowledge creation, sharing and utilisation (Kannan \& Aulbur, 2004). The IC Components perspective offers more vivid insights about each element of IC, and thus can identify where corrective actions might be required. However, it has been criticised as only providing a 'snapshot' evaluation of an organisation's knowledge, and thus only reflecting its static knowledge stocks without considering the dynamic element represented in its knowledge flows (Bontis, 2001; Lerro et al, 2012). Finally, the performance (or outcome) perspective provides some indications of correlations between KM and performance, but can suffer from being built on the questionable assumption that changes in organisational performance are solely due to $\mathrm{KM}$ disregarding the (perhaps many) other possible endogenous and exogenous influences on firm performance (Yu et al, 2007).

\section{The MinK framework}

The authors have endeavoured to benefit from the considerable amount of extant knowledge measurement literature to develop a new individual measurement model. First, they adopted the view that the absolute quantity of knowledge an individual holds cannot be measured via a direct formula -as it is both intangible and contextual - but that assessing certain of the individual's attributes and actions could provide a good indication of the knowledge they hold, acquire and share. Thus, instead of measuring knowledge itself, characteristics that indicate that knowledge is present within an individual, referred to as Individual Knowledge Indicators (IKIs), would be identified and assessed. MinK therefore proposes ten IKIs (listed in Table 3), each of which implies that an individual holds certain knowledge that is valuable to their organisation, or is active in acquiring and/or sharing such knowledge.

Second, the authors preferred not to rely on a single perspective when developing IKIs, but instead amalgamated the three knowledge measurement perspectives identified in the organisational knowledge measurement literature to propose IKIs that are tailored to address individuals, yet build on previous research efforts and hence reflect financial factors, performance outcomes and knowledge stocks (analogous to organisational IC models). The authors also incorporated a fourth perspective to reflect dynamic knowledge flows, one that IC models have 
Table 2 IC Components measurement models

\begin{tabular}{|c|c|c|c|c|}
\hline Framework & IC Classification & Metric Development & Aggregation & Financial Valuation \\
\hline $\begin{array}{l}\text { Skandia Navigator } \\
\text { (Edvinsson \& Malone, } \\
\text { 1997) }\end{array}$ & $\begin{array}{l}\text { - Human Capital } \\
\text { - Structural Capital } \\
\circ \text { Customer Capital } \\
\circ \text { Organisational Capital } \\
\text { - Process Capital } \\
\text { - Innovation Capital }\end{array}$ & $\begin{array}{l}\text { - Developed } 112 \text { metrics that } \\
\text { cover five components of IC }\end{array}$ & $\begin{array}{l}\text { - Combines all financial indicators } \\
\text { into a single monetary value } C \\
\text { - Converts all the remaining metrics } \\
\text { into ratios, and then aggregates } \\
\text { them into an efficiency indicator } I\end{array}$ & $\begin{array}{l}\text { The overall financial } \\
\text { value of IC is equal to } \\
\text { I multiplied by } C\end{array}$ \\
\hline IC Index (Roos et al, 1998) & $\begin{array}{l}\text { - Human Capital } \\
\text { (thinking part) } \\
\circ \text { Competence } \\
\circ \text { Attitude } \\
\circ \text { Intellectual Agility } \\
\text { - Structural Capital } \\
\text { (non-thinking part) } \\
\circ \text { Relationships } \\
\circ \text { Organisation } \\
\circ \text { Renewal and Development }\end{array}$ & $\begin{array}{l}\text { - Does not propose specific } \\
\text { metrics } \\
\text { - Provides a framework by } \\
\text { which every organisation } \\
\text { would set its own metrics in } \\
\text { light of its strategy, } \\
\text { characteristics and the } \\
\text { surrounding environment }\end{array}$ & $\begin{array}{l}\text { - Metrics must be expressed as a } \\
\text { dimensionless numbers } \\
\text { - Metrics are assigned weights to } \\
\text { reflect their relative importance, } \\
\text { and are aggregated into a single } \\
\text { index using a weighted average }\end{array}$ & $\begin{array}{l}\text { Indicates that the } \\
\text { behaviour of a } \\
\text { correctly designed IC } \\
\text { Index should be } \\
\text { correlated to financial } \\
\text { value of the } \\
\text { company. }\end{array}$ \\
\hline $\begin{array}{l}\text { Intangible Assets Monitor } \\
\text { (Sveiby, 1993, 1997) }\end{array}$ & $\begin{array}{l}\text { - Internal Structure } \\
\text { - External Structure } \\
\text { - Human Competence }\end{array}$ & $\begin{array}{l}\text { - Proposes indices to measure } \\
\text { each IC component from } \\
\text { three perspectives: } \\
\circ \text { Growth and renewal } \\
\circ \text { Efficiency } \\
\circ \text { Stability }\end{array}$ & $\begin{array}{l}\text { - Visually presents IC components' } \\
\text { strengths and weaknesses in an } \\
\text { aggregated tabular form, but } \\
\text { provides no numerical aggregation }\end{array}$ & $\begin{array}{l}\text { - No financial } \\
\text { valuation. }\end{array}$ \\
\hline $\begin{array}{l}\text { IC Rating (Jacobsen et al, } \\
\text { 2005) }\end{array}$ & $\begin{array}{l}\text { - Human Capital } \\
\circ \text { Management } \\
\circ \text { Employees } \\
\text { - Organisational Capital } \\
\circ \text { Process } \\
\circ \text { Intellectual Properties } \\
\text { - Relational Capital } \\
\circ \text { Network } \\
\circ \text { Brand } \\
\circ \text { Customers } \\
\text { - Business Recipe }\end{array}$ & $\begin{array}{l}\text { - Evaluates } 200 \text { parameters } \\
\text { through in-depth interviews } \\
\text { with internal and external } \\
\text { stakeholders } \\
\text { - Assesses IC components from } \\
\text { the perspectives of: } \\
\circ \text { Effectiveness } \\
\circ \text { Risk } \\
\circ \text { Renewal }\end{array}$ & $\begin{array}{l}\text { - Results are presented using a letter } \\
\text { grading system ranging from 'AAA' } \\
\text { to ' } \mathrm{D} \text { ' in one diagram, but no } \\
\text { numerical aggregation is } \\
\text { conducted }\end{array}$ & - No financial valuation \\
\hline
\end{tabular}


Table 3 Individual Knowledge Indicators (IKIs)

\begin{tabular}{|c|c|}
\hline IKI & Description \\
\hline Education & $\begin{array}{l}\text { An individual's formal academic education } \\
\text { (e.g. B.Sc., M.B.A., Ph.D.) }\end{array}$ \\
\hline Training & $\begin{array}{l}\text { Training courses and internships an individual } \\
\text { has attended during their career }\end{array}$ \\
\hline Experience & $\begin{array}{l}\text { The extent of an individual's professional } \\
\text { experience }\end{array}$ \\
\hline IT Literacy & $\begin{array}{l}\text { An individual's ability to use IT tools } \\
\text { (software and hardware) in business to } \\
\text { acquire, create and share knowledge }\end{array}$ \\
\hline $\begin{array}{l}\text { Business } \\
\text { Communications }\end{array}$ & $\begin{array}{l}\text { The nature, rate and patterns of an } \\
\text { individual's internal and external business } \\
\text { communications via different means } \\
\text { (meetings, phone calls, emails, etc.) }\end{array}$ \\
\hline $\begin{array}{c}\text { Business Process } \\
\text { Interactions }\end{array}$ & $\begin{array}{l}\text { The level of an individual's interaction with } \\
\text { business processes, both internal and } \\
\text { external to the organisation }\end{array}$ \\
\hline $\begin{array}{l}\text { Personal } \\
\text { Network }\end{array}$ & $\begin{array}{l}\text { The size and quality of an individual's } \\
\text { network of business contacts }\end{array}$ \\
\hline Performance & $\begin{array}{l}\text { An individual's performance at work and } \\
\text { overall contribution to their organisation }\end{array}$ \\
\hline $\begin{array}{l}\text { Creativity/ } \\
\text { Innovation }\end{array}$ & $\begin{array}{l}\text { An individual's ability to generate new ideas } \\
\text { and solutions to address existing problems }\end{array}$ \\
\hline $\begin{array}{l}\text { Financial } \\
\text { Indicators }\end{array}$ & $\begin{array}{l}\text { The financial value of an individual on the job } \\
\text { market and the market cost of the services } \\
\text { they provide }\end{array}$ \\
\hline
\end{tabular}

been criticised in the literature for overlooking (Lerro et al, 2012).

In light of the literature, IKIs can be grouped as follows:

- The first four IKIs (education, training, experience, IT literacy) can be seen as knowledge stock indicators, which are background indicators that provide static measures of individuals' stocks of knowledge, reflecting the knowledge they can be presumed to have acquired based on their history and background (Bolisani \& Oltramari, 2012).

- The next three IKIs (business communications, business process interactions, personal network) are knowledge flow indicators, process measures that reflect an individual's exposure to knowledge flows and their likely roles in knowledge acquisition and/or sharing (Malhotra, 2003).

- The following two IKIs (performance and creativity) are knowledge utilisation indicators, which, as output measures, reflect the effects the knowledge individuals hold has had on their work performance. Including this perspective was essential, as employees' knowledge stocks will only be of value to their organisations if they are used to improve performance and gain a sustainable competitive advantage (Baron, 2011).

- Finally, the last indicator reflects the financial methods suggested in the literature by using financial figures associated with individuals as proxy indicators of their knowledge. 
Table 4 Metrics for each individual knowledge indicator

\begin{tabular}{llll}
\hline & \multicolumn{2}{c}{ Knowledge Stock Indicators } \\
\hline Education & Training & Experience & IT Literacy \\
\hline - Level of education $(r)$ & $\bullet$ Professional qualifications $(r)$ & $\bullet$ Professional years (\#) & $\bullet$ General IT Literacy $(r)$ \\
- Grades (\%) & $\bullet$ Training hours (\#) & $\bullet$ Years in industry (\#) & (windows, office, internet) \\
- Relevance of education to job $(r)$ & $\bullet$ Training expense $(\$)$ & $\bullet$ Years in function (\#) & $\bullet$ Specific IT literacy $(r)$ \\
& $\bullet$ Internships $(n)$ & (e.g., finance) & $\bullet$ (function-specific software)
\end{tabular}

\begin{tabular}{|c|c|c|}
\hline \multicolumn{3}{|c|}{ Knowledge Flow Indicators } \\
\hline Business Communication & Business Process Interactions & Personal Network \\
\hline $\begin{array}{l}\text { - Meetings attended per week (\#) } \\
\text { - Meetings with managers per week (\#) } \\
\text { - Meetings with subordinates per week (\#) } \\
\text { - Meetings per week with external } \\
\text { stakeholders (\#) } \\
\text { - Communications sent per week (\#) } \\
\text { - (phone/email/memo/report) } \\
\text { - Communications received per week (\#) }\end{array}$ & $\begin{array}{l}\text { - Processes utilised (\#) } \\
\text { - Processes supervised (\#) } \\
\text { - Processes reviewed/audited (\#) } \\
\text { - Process improvement suggestions (\#) } \\
\text { - Process improvement suggestions } \\
\text { implemented (\#) } \\
\text { - Business process quality systems } \\
\text { - } \text { involvement (e.g., ISO) }(r) \\
\text { - Contribution to information systems (r) }\end{array}$ & $\begin{array}{l}\text { - Contacts (\#) } \\
\text { - Relevance of contacts to } \\
\text { business }(r) \\
\text { - No. of social media connections (\#) } \\
\text { - Percentage of external contacts (\%) } \\
\text { - Percentage of international contacts (\%) } \\
\text { - Percentage of 'VIP' contacts (\%) } \\
\text { - New contacts acquired/month (\#) } \\
\text { - Business contacts retention ( } r)\end{array}$ \\
\hline
\end{tabular}

\begin{tabular}{|c|c|}
\hline \multicolumn{2}{|c|}{ Knowledge Utilisation Indicators } \\
\hline Performance & Creativity/Innovation \\
\hline $\begin{array}{l}\text { - Performance appraisal }(r) \\
\text { - Productivity }(r) \\
\text { - Cost savings }(\$) \\
\text { - Income generated/sales }(\$) \\
\text { - Percentage of target(s) achieved (\%) }\end{array}$ & $\begin{array}{l}\text { - New ideas suggested (\#) } \\
\text { - New ideas implemented (\#) } \\
\text { - Patents (\#) }\end{array}$ \\
\hline \multicolumn{2}{|c|}{ Financial Indicators } \\
\hline $\begin{array}{l}\text { - Recruitment/replacement costs }(\$) \\
\text { - Compensation }(\$)\end{array}$ & $\begin{array}{l}\text { - Market cost of equivalent services }(\$) \\
\text { - Investment in training }(\$)\end{array}$ \\
\hline
\end{tabular}

The next step was to develop metrics to assess each IKI. Metrics are measurement units, which may be direct counts, monetary values or percentages when used to measure quantitative attributes, or numerical scale-based ratings when used to quantify qualitative attributes (Lerro et al, 2012). Table 4 shows the proposed metrics for each indicator, along with their corresponding units of measurement (where ' $\#$ ' is a number, ' $\%$ ' a percentage, ' $\$$ ' a monetary value and ' $r$ ' a rating).

\section{Preliminary validation study}

Before proceeding to the second phase of this research, it was necessary to examine the validity of the proposed indicators and metrics as measures of individual knowledge. A preliminary validation study was conducted via semi-structured interviews of a sample of 15 senior managers and directors representing small, medium and large corporations from nine different industries and located across nine countries (Table 5 gives their profiles). Respondents were selected from diverse backgrounds so as to examine the generalisability of MinK across different disciplines, company sizes and countries.

Interviews started by providing background information about knowledge measurement and briefly explaining MinK. The first few questions examined respondents' awareness of knowledge management and measurement in their own organisations and the KM challenges they were currently facing. Participants were then asked to complete an evaluation questionnaire to assess the relevance of the proposed indicators and metrics to measuring individual knowledge using a five-point Likert scale (Likert, 1932) ranging from 1 (highly irrelevant) to 5 (highly relevant). The questionnaire was then discussed and the managers gave further insights related to their answers, as well as their reflections and opinions on the suitability and potential of the MinK framework. 
Table 5 Pilot study of respondents' profiles

\begin{tabular}{|c|c|c|c|c|}
\hline Position & Company Name & Company Description & No. of Employees & Location \\
\hline Managing Director & Brand Essence & Marketing consulting company & 6 & Egypt \\
\hline HR Consultant & MT Personnel & Training and HR consulting company & 9 & South Africa \\
\hline Chief Scientist & EZOSA Solutions & Software research company & 9 & USA \\
\hline Business Development Manager & HHDC & Healthcare development contractor & 25 & Lebanon \\
\hline Sales Manager & AstraZeneca & Multinational Pharmaceutical Company & 150 & Dubai \\
\hline Associate Professor & Macalester College & Private college & 174 & U.S.A. \\
\hline Business Development Advisor & $\mathrm{EIO}$ & Medical equipment supplier & 300 & Egypt \\
\hline Managing Director & Multiples Group & Private equity and investment advisory & 400 & Egypt \\
\hline Vice-President, Quality Assurance & Pharos University & Private university & 1000 & Egypt \\
\hline Channel Marketing Manager & Unilever & Multinational consumer goods manufacturer & 1800 & Egypt \\
\hline Head of School & Dublin Institute of Technology & Public university & 2000 & Ireland \\
\hline Head of Procurement & Google & Online services provider & 5300 & Germany \\
\hline Account Manager & Schlumberger & Oilfield services company & 56,000 & Iraq \\
\hline Supply Planning Manager & Mars Inc. & Multinational food manufacturer & 70,000 & Saudi Arabia \\
\hline Operations Manager & Procter \& Gamble & Multinational consumer goods manufacturer & 126,000 & Saudi Arabia \\
\hline
\end{tabular}

\section{Findings and Feedback}

During initial discussions, participants seemed familiar with KM, and most reported that their organisations implemented some sort of people-based or IT-based KM activity, of which the most interesting was an interactive virtual 'knowledge marketplace' on which employees were encouraged to 'sell' knowledge to their colleagues from their 'kiosks' in return for virtual 'stars'. However, most respondents indicated that their organisations were still suffering from knowledge loss, primarily due to staff turnover. When introduced to MinK, all respondents emphasised the value of individual knowledge and expressed interest in the idea of its measurement. Half of the participants reported that their organisations attempted to measure individual knowledge, mostly by performance appraisals, managerial assessments, or self-assessments.

Analysis of the respondents' evaluations of MinK based on the questionnaire responses showed that IKIs were highly rated, with nine out of ten indicators gaining average ratings of over 4 (see Figure 1). The lowest average rating of 3.4 was given to financial indicators, which was seen as the least relevant IKI. Half the respondents questioned the relationship between compensation and knowledge, because they believed that knowledgeable employees were often underpaid and less knowledgeable ones are sometimes overpaid. Furthermore, three participants offered an interesting suggestion by recommending a new IKI to represent 'interpersonal skills' or 'the ability to convey knowledge' as an additional knowledge flow indicator. Nevertheless, the overall outcome of this evaluation of the proposed IKIs was highly positive, with interviewees unanimously agreeing that, collectively, MinK's indicators provided 'a good indication of individual knowledge'.

When evaluating metrics, the metrics for six of the ten proposed indicators received average ratings of 4 or higher (see Figure 2). Those participants who found financial indicators unconvincing also gave low ratings to financial metrics. Metrics associated with the Business

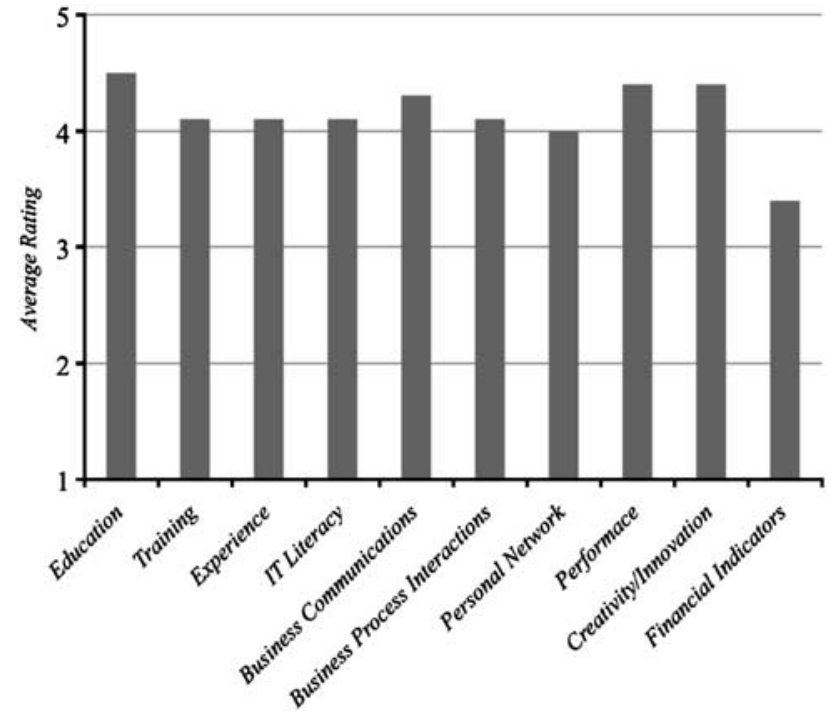

Figure 1 Questionnaire results: evaluations of indicators (IKIs).

Communications and Personal Network IKIs, which were based on direct counts (e.g., number of contacts, number of emails per day), were rated lower and criticised as not being truly relevant to their corresponding IKIs because they measured the 'quantity' and not the 'quality' of the network and communications. As one manager stated, 'an employee can attend a number of meetings and receive hundreds of emails per day only for bureaucratic tasks that would have limited effect on her or his individual knowledge'. Similarly, many participants doubted that the costs of training were necessarily related to the value of the knowledge acquired during training.

Overall, the results of this preliminary study suggest that MinK was validated as a framework to measure knowledge, and that its ten IKIs represented different and relevant facets of an individual's knowledge stocks and flows. 


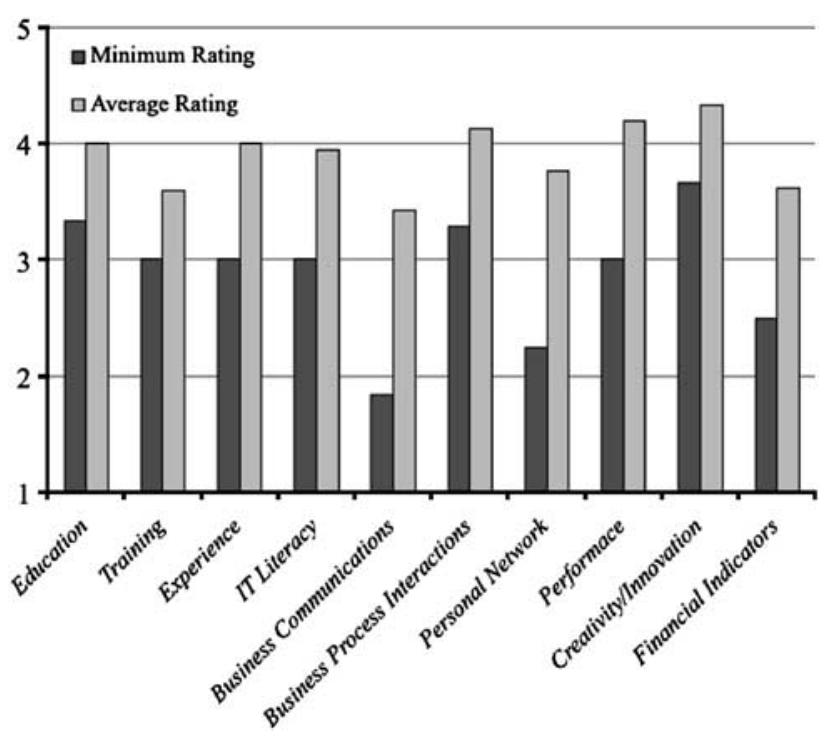

Figure 2 Questionnaire results: evaluation of metrics.

However, respondents' reactions also implied that some metrics might not have been the most suitable for each IKI, indicating that further development of metrics is required. The authors found that respondents' comments gave them valuable feedback, which they could use to improve MinK, particularly by looking for other metrics for measuring certain IKIs that could address the criticism that quantity does not necessarily lead to quality.

\section{References}

AL-LAHAM A, TZABbar D and AmburGeY TL (2011) The dynamics of knowledge stocks and knowledge flows: innovation consequences of recruitment and collaboration in biotech. Industrial and Corporate Change 20(2), 555-583.

BARON A (2011) Measuring human capital. Strategic HR Review 10(2), 30-35.

BODA G and SZLAVIK P (2007) Alternative accounting to manage intellectual capital. Electronic Journal of Knowledge Management 5(1), 7-18.

BOLISANI E and OLtramarI A (2012) Knowledge as a measurable object in business contexts: a stock-and-flow approach. Knowledge Management Research \& Practice 10(3), 275-286.

BONTIS N (2001) Assessing knowledge assets: a review of the models used to measure intellectual capital. International Journal of Management Reviews 3(1), 41-60.

BONTIS N and CROSSAN MM and Business RISO (1999) Managing an Organisational Learning System by Aligning Stocks and Flows of Knowledge: An Empirical Examination of Intellectual Capital, Knowledge Management, and Business Performance. University of Western Ontario, Ontario.

BOSE R (2004) Knowledge management metrics. Industrial Management \& Data Systems 104(6), 457-468.

BROOKING A (1996) Intellectual Capital. Thomson Learning.

CARMELI A and TISHLER A (2004) The relationships between intangible organisational elements and organisational performance. Strategic Management Journal 25(13), 1257-1278.

Chen M, HuANG M and CHeNG Y (2009) Measuring knowledge management performance using a competitive perspective: an empirical study. Expert Systems with Applications 36(4), 8449-8459.

\section{Conclusion and future work}

This study presented the first phase in the development of MinK, a framework designed to measure individual knowledge in a business context to address an existing gap in the literature and, more importantly, to help organisations manage their knowledge more effectively by identifying individual knowledge holders. Ten indicators denoting individuals' knowledge stocks, flows and performance were selected and metrics were developed to assess individuals' knowledge characteristics for each indicator. As a preliminary validation exercise, a study was conducted through semi-structured interviews with managers from different industries. Overall, the framework of indicators was rated highly, and their associated metrics well, and the managers who contributed to the study provided useful insights and recommendations that the authors will consider in developing the final version of MinK.

The main limitation of the preliminary validation stage was the sample size, and thus the authors plan to include more companies and a larger scale of contributions from top management from a wider variety of organisations in the subsequent phase. The MinK framework will then be modified to incorporate valid suggestions that emerge from the two validation phases.

\section{Acknowledgement}

The authors would like to thank Pharos University in Alexandria, Egypt, for its support of this research.

DAVENPORT T and PRUSAK L (2000) Working Knowledge: How Organisations Manage What They Know. Harvard Business Press.

EDVINSSON L (1997) Developing intellectual capital at Skandia. Long Range Planning 30(3), 366-373.

EDVINSSON L and MALONE M (1997) Intellectual Capital: Realising Your Company's True Value by Finding Its Hidden Brainpower. Harper Business, New York.

FAHEY L and PRUSAK L (1998) The eleven deadliest sins of knowledge management. California Management Review 40(3), 265-276.

FlamHoltz EG, KanNAN-NARASIMHAN R and BulLeN ML (1993) Human resource accounting today: contributions, controversies and conclusions. Journal of Human Resource Costing \& Accounting 8(2), 23-37.

GalbraitH JK (1969) The New Industrial State. Princeton University Press, Princeton.

HEISIC P (2009) Harmonisation of knowledge management - comparing $160 \mathrm{KM}$ frameworks around the globe. Journal of Knowledge Management 13(4), 4-31.

HeRMANSON RH (1964) Accounting for Human Assets. Bureau of Business and Economic Research, Graduate School of Business Administration, Michigan State University, Michigan.

HUANG MJ, Chen MY and YIEH K (2007) Comparing with your main competitor: the single most important task of knowledge management performance measurement. Journal of Information Science 33(4), 416-434.

JACOBSEN K, HOFMAN-BANG P and NORDBY Jr. R (2005) The IC rating. Journal of Intellectual Capital 6(4), 570-587.

KANNAN G and AULBUR WG (2004) Intellectual capital: measurement effectiveness. Journal of Intellectual Capital 5(3), 389-413. 
KAPLAN R and NORTON D (1996) The Balanced Scorecard: Translating Strategy into Action. Harvard Business Press.

KHALIFA M, YU A and SHEN K (2008) Knowledge management systems success: a contingency perspective. Journal of Knowledge Management 12(1), 119.

LERro A, IACOBONE FA and SCHIUMA G (2012) Knowledge assets assessment strategies: organizational value, processes, approaches and evaluation architectures. Journal of Knowledge Management 16(4), 563-575.

LIEBOWITZ J and SUEN C (2000) Developing knowledge management metrics for measuring intellectual capital. Journal of Intellectual Capital 1(1), 54-67.

LIEBOWITZ J and WRIGHT K (1999) Does measuring knowledge make 'cents'? Expert Systems with Applications 17(2), 99-103.

LIKERT R (1932) A technique for the measurement of attitudes. Archives of Psychology.

LUTHY D (1998) Intellectual capital and its measurement. Proceedings of the Asian Pacific Interdisciplinary Research in Accounting Conference (APIRA). Osaka, Japan.

MALHOTRA Y (2003) Measuring knowledge assets of a nation: knowledge systems for development. Invited Research Paper sponsored by the United Nations Department of Economic and Social Affairs. Keynote Presentation at the Ad Hoc Group of Experts Meeting at the United Nations Headquarters, New York City, NY. Citeseer.

Marr B, SChiuma G and Neely A (2004) Intellectual capital: defining key performance indicators for organizational knowledge assets. Business Process Management Journal 10(5), 551-569.

NONAKA IA and TAKEUCHI HA (1995) The Knowledge-Creating Company: How Japanese Companies Create the Dynamics of Innovation. Oxford University Press.

PACHARAPHA T and RACTHAM V (2012) Knowledge acquisition: the roles of perceived value of knowledge content and source. Journal of Knowledge Management 16(5), 724-739.

\section{About the authors}

Mohamed A.F. Ragab is a Ph.D. researcher in the 3S Group, College of Business, Dublin Institute of Technology (DIT) and the Secretary General of Pharos University in Alexandria (PUA), Egypt. He received his BSc degree specialised in Industrial Engineering and his MBA degree specialised in Management from the American University in Cairo (AUC). His research interests include Knowledge Management and Simulation Modeling.
Petra A and ANNelies W (2012) Disentangling value-enhancing and costincreasing effects of knowledge management. Journal of Knowledge Management 16(3), 387-399.

PULIC A (2000) VAICTM - an accounting tool for IC management. International Journal of Technology Management 20(5), 702-714.

Roos J, Edvinsson L and Roos G (1998) Intellectual Capital: Navigating in the New Business Landscape. New York University Press.

Serenko A, Bontis N, Booker L, SADEDdin K and HARDIE T (2010) A scientometric analysis of knowledge management and intellectual capital academic literature (1994-2008). Journal of Knowledge Management 14(1), 3-23.

SkYRME D (2003) Measuring Knowledge and Intellectual Capital. Business Intelligence.

SKYRME D (2005) Measuring knowledge: a plethora of methods. Skyrme knowledge connections. [WWW document] http://www.skyrme .com/insights/24kmeas. htm (accessed 15 January 2013).

STEWART B (1994) EVA: fact and fantasy. Journal of Applied Corporate Finance 7(2), 71-87.

STEWART T (1998) Intellectual Capital: The New Wealth of Organisations. Doubleday, New York, NY.

SVEIBY KE (1993) The intangible assets monitor. Journal of Human Resource Costing \& Accounting 2(1), 73-97.

SVEIBY KE (1997) The New Organizational Wealth: Managing \& Measuring Knowledge-Based Assets. Berrett-Koehler Publishers, San Francisco, CA.

TOBIN J (1969) A general equilibrium approach to monetary theory. Journal of Money, Credit and Banking 1(1), 15-29.

WEAVER SC (2001) Measuring economic value added: a survey of the practices of EVA proponents. Journal of Applied Finance 11(1), 50-60.

WICKHAM HA (2008) Practical tools for exploring data and models. [WWW document] http://www.had.co.nz/thesis/seminar.pdf (accessed 30 January 2013).

YU S, KIM Y and KIM M (2007) Do we know what really drives KM performance? Journal of Knowledge Management 11(6), 39-53.

Amr Arisha is the director of 3S Group, a research unit in Dublin Institute of Technology (DIT), and Head of Department of International Business at DIT. He has published over 30 journal and international conference articles in the area of system analysis and optimisation of business processes. He is a chief examiner and member of the Marketing Institute of Ireland, also a member of IEEE, IIE, IMECH, IEI, ESE, and ASME.

\section{Correction}

In the online version originally published 19th August 2013 the second author's name was misspelled. This has been corrected in this final version. 